OPEN ACCESS

Edited by:

Carol Kerven

University College London,

United Kingdom

Reviewed by:

Emily Woodhouse

University College London,

United Kingdom

Jarmila Ptackova,

Oriental Institute (ACSR), Czechia

${ }^{*}$ Correspondence:

Gongbuzeren

gongbuyak@swufe.edu.cn

Specialty section:

This article was submitted to Agroecology and Ecosystem Services,

a section of the journal

Frontiers in Sustainable Food Systems

Received: 30 September 2020

Accepted: 04 March 2021

Published: 09 April 2021

Citation:

Gongbuzeren, Wenjun $L$ and Yupei $L$

(2021) The Role of Community Cooperative Institutions in Building

Rural-Urban Linkages Under Urbanization of Pastoral Regions in

\section{The Role of Community Cooperative Institutions in Building Rural-Urban Linkages Under Urbanization of Pastoral Regions in China}

\author{
Gongbuzeren $^{1 *}$, Li Wenjun ${ }^{2}$ and Lai Yupei ${ }^{3}$ \\ ${ }^{1}$ Center for China's West Economic Development, Southwestern University of Finance and Economics, Chengdu, China, \\ ${ }^{2}$ College of Environmental Science and Engineering, Peking University, Beijing, China, ${ }^{3}$ Institute of Building Research Co., \\ Ltd., Shenzhen, China
}

In contrast to agricultural settings, the process of urbanization in the pastoral regions of China are largely driven by long-term influences of ecological conservation and the provision of social services. Consequently, many of the herders who have migrated into nearby secondary urban centers depend on resources from pastoral regions to support their livelihoods, forming complex patterns of rural-urban linkages. While current literature has discussed the processes of herder out-migration and their implications on rural and urban livelihood development, few studies have examined the linkages between the herders living in the pastoral regions and those who have out-migrated to urban regions and their importance in rural livelihood transformation. Based on past studies, we argue that, in a changing pastoral social-ecological system, herders living in both rural and urban regions depend on each other to support their livelihoods through three types of mobility: (1) livestock mobility, (2) herder mobility, and (3) resource mobility. However, what innovative institutions in rangeland resource management and herder economic cooperation can do to help maintain these three types of mobility to sustain rural livelihood development, becomes a critical challenge. Innovative community cooperative institutions developed by pastoral communities from the Tibetan Plateau and Inner Mongolia may be able to offer new perspective and insight on how to better maintain rural-urban linkages in the processes of urbanization in pastoral regions. In this current study will present the two cases of innovative institutions and the roles they play in facilitating the three types of mobility to address livelihood challenges. While current studies recommend an increase of government subsidies, provision of vocational training, and social insurance that help herders better adapt to urban livelihood, we argue that rangeland management and community economic cooperation in innovative institutions are needed to facilitate the mobility of livestock, resources, and the herder population, and maybe only then the livelihood challenges that migrated herders are facing will be addressed effectively.

Keywords: urbanization, rangeland institution, herder cooperative, grazing quota system, pastoral region 


\section{INTRODUCTION}

Rangelands cover 400 million ha, accounting for $41.7 \%$ of China's total territory, among which $3 / 4$ of the rangelands are distributed mainly in China's west regions (MOA, 2014). These regions are mostly located in arid and semi-arid regions and alpine steppes with either a long cold season or a dry hot season (Sheehy et al., 2006; Li and Zhang, 2009). These are some of the world's poorest and most marginalized areas but also some of the most innovative and enterprising, responding to environmental, market, and governance uncertainties in ways that can offer vital insights elsewhere (Scoones et al., 2020). In the contemporary context of social-ecological changes, pastoral communities in China are being rapidly integrated into multilevel networks characterized by deep uncertainties, including climate variability and environmental change, a volatile market and financial systems, the increasing mobility of the population that has resulted in the reconfiguration of rural socio-economic structures, resource use and access rights, and institutional arrangements (Gongbuzeren et al., 2018; Nori and Scoones, 2019; Qi and Li, 2021). Urbanization of pastoral regions is one of these great socio-economic transformations that has increased the movement of herder populations between rural and urban areas and has restructured rural livelihoods (Bao and Shi, 2020).

In contrast to urbanization in the agricultural regions of China, where population out-migration are voluntary movements induced by marketization and economic opportunities (Jin and Li, 2019), the urbanization processes in pastoral regions are driven by long-term interactive influences of multiple policies including rangeland ecological conservation policies (caoyuan shengtai jianshe), the rural school consolidation policy (chedian Bingxiao), rangeland institutional reforms (caochang zhidu gaige), and rural poverty alleviation programs (tuoping gongjian zhengce) (Washul, 2018; Bao and Shi, 2020). In particular, ecological conservation programs including "retired grazing to restore grassland" (tuimu huancao) and "ecological migration program (Shengtai Yiming)" are among the major strategies that have encouraged pastoral households to resettle in townships and county seats (Ptackova, 2011; Du, 2014; Jiumaocuo and Wang, 2016). Scholars also discovered that the Rural School Consolidation Policy, which was launched nationally in 2001 and implemented in various Tibetan areas at later dates, has spurred the closing of the majority of village schools, and rural children are now forced to live in boarding schools in distant townships or county seats, starting from an early age (Bum, 2018; Yeh and Makely, 2019). This policy further accelerated the out-migration of many rural herders to resettle in adjacent sub-urban regions. Herder out-migration in pastoral regions has therefore been driven by top-down policy interventions, integration of rural pastoral regions into marketization, and voluntary herder movements (Wang and Xiu, 2014; Jin and Li, 2019). In this process, two major patterns of out-migration have emerged to form complex rural-urban linkages. First, the whole pastoral family resettles in urban areas, though many of them cannot find viable income sources in urban regions, so they continue to rely on resources from pastoral regions, including the collection of caterpillar fungus and livestock production, to support their livelihoods in the urban area. Second, family members live separately in two regions, where elders accompany their children to live in the urban areas while young people from the family stay in the pastoral regions to maintain their livestock production and to support their livelihoods. Therefore, unlike agricultural regions where labor out-migration tends to explore alternative income sources to support their rural home, out-migrated herders depend on rural rangeland resources to support their livelihood and expenditures in urban regions.

As urbanization processes in pastoral regions have been accelerated with complex patterns of herder population mobility, there has been an emerging number of studies in recent years, focusing on the impacts of urbanization on the herder population and their livelihoods. Using "urbanization in pastoral regions" as a keyword to do a search in CNKI, we have discovered that over 143 journal papers that were written in the Chinese language were published between 1999 and 2020 that focus on the urbanization of pastoral regions. These journal papers focus mainly on three major themes about urbanization in the pastoral regions. First, many of the past studies focus on the pull and push factors of herder out-migration (Dai et al., 2009; Jin and Li, 2019). These studies argue that policy-driven out-migration such as ecological migration programs and rural school consolidation policies are the push factors for involuntary migration, which cover the majority of rural herder population movements (Fan et al., 2015). Others argue that the young generation is showing a high level of unwillingness to continue pastoralism livelihood, which is a major push factor, and the desire to find stable jobs is a pull factor for voluntary migration (Dai et al., 2009; Li, 2012). However, studies also discovered some patterns of herders moving back to pastoral regions after a few years of living in the urban and suburban regions as they could not find stable income sources (Du, 2014; Wang and Xiu, 2014). Second, with a high level of herder mobility, studies focus on herders' ability to adapt to urban socio-economic structures and their livelihood development challenges. Regarding this, even though some studies argue that herder resettlement improved access to better education and healthcare, with more opportunities to diversify their income (Liu and Wang, 2008), many studies gradually discovered a variety of challenges affecting their livelihood, with increased wealth differentiation (Li, 2012, 2013; Fan et al., 2015; Gongbuzeren et al., 2015; Zhang, 2020). In many cases, studies discovered that herders have poor technical skills and low literacy levels which limit their ability to find viable employment, and even those who are able to find jobs usually have low-paying ones (Zhu, 2018; Jin and Li, 2019). In addition, there have been all types of discrimination toward the migrated herders from the original urban residents that further exacerbate out-migrated herders' ability to adapt to urban livelihood (Li, 2012). Consequently, studies argue that out-migrated herders have encountered both livelihood poverty and the challenges of social marginalization and cultural isolation. Many of those outmigrated families, therefore, have relied on government subsidies as their main source of livelihood. To address these issues, many studies recommend increasing government subsidies, provision 
of social insurances including medical insurances, and targeted vocational training that could help the migrated herders find better employment and income sources (Wang and Xiu, 2014). Third, there are also studies that argue that herders should not leave pastoral regions as livestock production and grazing activities are part of the pastoral social-ecological systems that not only sustain herder livelihoods but also protect rangeland ecosystems and biodiversity. In summary, these studies argue that policies should pay greater attention to innovative strategies that could provide social services and develop markets for livestock production while keeping herders in the pastoral regions rather than forcing them to move to urban regions (Gongbuzeren et al., 2015).

The number of studies focusing on the urbanization of pastoral regions has increased in recent years and has provided empirical information and understanding on the pull-push factors of herder out-migration and their livelihood challenges. However, these studies focus either on migrated herder populations and their livelihoods or on those herders who remained in the pastoral regions and their socio-economic and ecological issues, while many failed to capture the coupled feedback and linkages between the herders living in pastoral regions and those who are being resettled in urban regions. Studies argue that rural livelihood transformation under urbanization is a long-term process where herders living in both urban and rural regions need to depend on complex patterns of linkages between rural and urban regions to access markets and rangeland resources that sustain their livelihood (Huntsinger et al., 2010; Eriksson, 2011; Du, 2014; Fan et al., 2015; Zhang, 2020). We therefore argue that we need to frame the issues of urbanization in the pastoral regions from a perspective of seeing the rural and urban regions as a coupled system. Based on the social-ecological features of pastoral regions, we have developed three conceptual mobility types that we believe could maintain rural-urban linkages to address herder livelihood changes under an accelerated process of urbanization. These three types of mobilities include livestock mobility, herder mobility, and resource mobility.

First, livestock mobility is a major characteristic of traditional pastoral systems globally, a production and coping strategy that facilitates greater levels of livestock production, use of shared labor, escape from localized drought or cold, access to landscape heterogeneity, and use of widely dispersed water sources (Behnke et al., 1993; Li and Huntsinger, 2011; Kratli, 2019). However, when the Rangeland Household Contract System was implemented in the late 1990s, allocated pastures were fenced, land use as well as tenure became fragmented, and the scale of herder movements was reduced (Li and Zhang, 2009; Gongbuzeren et al., 2015). The larger spatiotemporal scales of herd mobility that were formerly possible are no longer feasible (Gongbuzeren, 2019). Community relationships based on reciprocity, which supported shared pasture use and labor, are also fragmented as households focus on earning a livelihood from individual pastures (Li and Huntsinger, 2011). This has created an institutional controversy and dilemma for both groups of herders living in pastoral regions and urban areas. On one hand, individualized tenure has reduced their ability to access seasonal pastures for herders who stay in the pastoral regions and has increased livestock production costs. Many of those out-migrated herders who still keep livestock in the pastoral regions face similar challenges. Therefore, recent scholars and policymakers also recommend institutional changes that encourage the reaggregation of individual rangeland resources and restoration of community collective use of rangelands (State Council, 2016; Li et al., 2018; Qi and Li, 2021). However, on the other hand, studies also discovered that the increased level of herder out-migration increased conflicting values and competing priorities over the use and management of rangeland resources within pastoral communities (Kamoto et al., 2013; Gongbuzeren et al., 2018). Rural communities who have collectively used their natural resource may now find themselves with individuals, especially out-migrated herders, who do not have livestock, demanding more privatized and clarified property rights to protect individual benefits and opportunities (Gongbuzeren, 2019). Therefore, how to restore or maintain community collective use of rangelands and seasonal livestock mobility while protecting individual tenure security and benefits becomes a critical challenge.

Second, the improved infrastructures in China's rural regions and the increasing commodification and extension of capitalist systems of production in rural regions have diversified the use of and the economic values of the rangelands (Thornton and Manasfi, 2010; Cleaver, 2012; Chaudhury et al., 2017), increasing herder mobility and resource mobility between rural and urban regions. On the one hand, under current socio-economic changes, rangelands not only support livestock production but they also provide resources for the development of ecotourism, the collection of lucrative medicinal herbs such as caterpillar fungus, and the rental of grazing lands to earn a fee (Gongbuzeren et al., 2018). In particular, the development of the rural tourism industry in the pastoral regions of the Tibetan Plateau in the last decade has increased with a massive number of tourists visiting rural pastoral communities, creating all types of consumer markets for rural livestock products and cultural artifacts. Therefore, migrated herders continuously move between urban and rural regions to access resources from the rangeland to support their livelihoods while they explore other livelihood options in urban regions (Jin and Li, 2019; Bao and Shi, 2020; Zhang, 2020). On the other hand, the number of cultural industries and businesses such as Tibetan restaurants and cultural performance centers have also increased in urban and suburban regions. Members of rural pastoral families are gradually moving into urban regions to engage with smallscale business opportunities or get temporary employment in these culturally related business entities. Therefore, even though livestock production and other resources from rangelands are the main sources of livelihood for herders who stay in pastoral regions, they also try to participate in current markets to explore other income opportunities. Given this, both groups of herders living in rural and urban regions constantly move between rural and urban regions to access resources, forming complex patterns of herder and resource mobility.

We argue that livestock mobility, herder mobility, and resource mobility are key features of rural-urban linkages in the process of urbanization in pastoral regions to address 
livelihood development challenges for herders living in rural and urban regions. However, maintaining all three types of mobilities creates critical challenges for rangeland management institutions and tenure regimes, as it requires institutions operating across multiple scales to rebuild cooperation and collective action among the herders. First, at the household scale, a clarified individual right is needed to protect individual benefits and use of rangeland resources for both groups of herders. Studies have raised critiques of traditional communitybased natural resource management institutions to have overfocused on community shared goals and common property rights while leading to the differentiated distribution of resources and power among individuals, which favor the powerful and disadvantage the marginal (Nightingale, 2011; Ojia et al., 2016). Therefore, clarification of rights at household scales to achieve equal distribution of rangeland resources and to facilitate resource mobility becomes fundamental (Gongbuzeren et al., 2018). Second, extensive research studies argue that community common property rights and management of rangelands are critical for maintaining seasonal livestock mobility with flexible access to rangeland resources to better adapt to ecological changes (Miehe et al., 2009; Gongbuzeren, 2019). In addition, studies also discovered that lucrative medicinal herbs such as caterpillar fungus only grow in certain regions of the community rangelands (Zhang, 2020). Restoration of common community property, therefore, will not only restore livestock mobility but will also facilitate resource mobility through guaranteed equal access to caterpillar fungus for all herders. Third, pastoralists are increasingly commercializing, often through local market connections and sometimes to lucrative international and regional markets (Scoones et al., 2020), and as a driver of social differentiation within pastoral populations, access to markets is key (Catley and Aklilu, 2013). However, some pastoralists are able to step up toward more commercial pastoral production systems, capitalizing on growing markets in livestock production, while others are simply hanging on, combing limited pastoral production with other activities, leading to "moving up, moving out" scenarios with increased wealth differentiation among herders living in rural and urban regions (Aklilu and Catley, 2010; Catley et al., 2013; Zhu, 2018). Therefore, studies encourage the development of institutions and a moral economy that is focused on rebuilding community cooperative economic entities with the sharing and redistribution of resources within pastoral communities to ensure that all herders living in a rural region and those being resettled in urban areas have access to, and gain benefits from markets (Zhu, 2018; Scoones et al., 2020). Finally, in rebuilding community cooperative economic entities, rural herders may be able to access resources and support from governments, civil societies, and markets at the regional level.

The need for institutional diversity and innovation are essential in maintaining livestock mobility, herder mobility, and resource mobility in pastoral rural-urban linkages. In 2016, after 30 years of implementing the Rangeland Household Contract Policy (RHCP), the Chinese government initiated "Suggestions on Improvement of Ownership Rights, Contractual Rights, and Use Rights in Rural Land" (sanquan fenzhi) to divide the existing two rights, ownership and contractual use rights, into three rights: ownership, non-tradable contractual rights, and tradable management rights (State Council, 2016). It has been argued that such land tenure reform can provide the institutional flexibility to re-aggregate individual rangeland resources and to rebuild cooperative business entities. However, in actual practice, studies have discovered that this policy has been mainly practiced through a rangeland rental system between individual households without being able to restore community cooperation (Lai and Li, 2012; Li et al., 2018; Gongbuzeren et al., 2020). Even though the land rental system generates income for some of the migrated herders, it does not effectively address the three types of mobilities to maintain rural-urban linkages in pastoral regions. Therefore, knowing what innovative institutions could help rural herders to rebuild community cooperation while protecting individual rights and benefits to maintain rural-urban linkages becomes a critical challenge.

We believe that some of the innovative rangeland institutions that are self-organized by rural pastoral communities in the pastoral regions of China may be able to offer critical insights and contributions to the issues discussed. According to our fieldwork, we believe that these newly emerged institutions can be categorized into two major featured groups. First, even though the government has promoted the rangeland household contract policy, in practice, however, many communities maintained collective management and use of rangelands, and based on community organization, herders self-organized a tradable grazing quota system to protect individual rights and benefits in recent years. Second, after the implementation of the rangeland household contract system with the building of wire fences to demarcate individual grazing boundaries, herders collaboratively decided to remove the fences and rebuilt community collective management of rangeland resources. At the same time, such a management system protected individual rights and benefits through the distribution of bundles of entitlements to resource and market access, such as entitlement to an equal share of investment stock in the community collective enterprises. In both groups, the pastoral communities have applied hybrids of informal customary rules and formal market-based institutions to restore community cooperation over the management of rangeland resources and participation in marketization, while redefining the networks and distribution of benefits and rights among individual herders. We believe that these self-reorganized institutional innovations provide an interesting perspective on how pastoral communities have evolved and changed through processes of urbanization to rebuild institutions that could maintain or restore livestock mobility, herder mobility, and resource mobility between herders living in rural regions and those being out-migrated in urban regions. We have presented two case studies from our past research to further illustrate how pastoral communities in China have developed innovative rangeland institutions and show the perspectives these cases present in advancing our understanding of the roles of community cooperative institutions in building ruralurban linkages. 


\section{CASE 1: COMMUNITY-BASED HERDER COOPERATIVE IN INNER MONGOLIA}

This section discusses a case of a community-based herder cooperative from the pastoral regions of Inner Mongolia. Inner Mongolia is one of the first pastoral regions that have strictly implemented the Rangeland Household Contract Policy, though after years of practicing this policy, innovative rangeland management institutions are emerging. This case of a herder cooperative is one such innovative community-based institution that re-aggregated individualized grazing areas to restore the collective community use of rangelands.

New Baerhu Right Banner is located in the northeast of Inner Mongolia, adjacent to the borders of Russia and Mongolia. The case study site, H Gacha (a village in Inner Mongolia), is in the northern part of the Banner, west of Hulun Lake. The community rangeland is a meadow steppe, with an average annual precipitation of around $189 \mathrm{~mm}$. In 2012, the village had a total of 44 households with 147 people; all of them are Mongolian. Livestock production is the main source of income. Herders mainly raised sheep, with a few goats, cattle, and horses.

In 1996, the village contracted their rangelands into individual households, with wire fences built to demarcate boundaries between individual grazing areas. However, after nearly 14 years of practicing this policy, herders in this village went through a variety of challenges (Lai, 2012). First, the high frequency of weather disasters, especially drought, led to high livestock mortality and pushed many families in the village to give up livestock production completely. By 2009, over half of the community households did not have livestock. Many of them either worked for other pastoral families to herd their livestock or moved out to adjacent urban towns to find alternative income sources. According to an interview from the studies of Lai (2012), many of these herders who had to give up livestock production earned a minimum income to support their livelihoods. Second, those pastoral households who do not have livestock, rented out their grazing areas to herders outside the village to earn an income, though this led to an increase in the overall grazing pressure in the community rangelands. Consequently, the community rangeland conditions have deteriorated, and many of the pastoral households had to spend more to purchase fodder and feed to supplement livestock foraging needs. Given these issues, the community decided to establish a herder cooperative, a community collective business entity in which all 44 households from the village participated.

The community cooperative applied several strategies to restore the community's collective use of rangelands and collective business entities (Lai, 2012). First, herders in the village can use either livestock or their contracted individual grazing areas as starting capital to participate in the cooperative, and all herders in the village are entitled to a stock share from the cooperative business. Second, as many individual grazing areas become part of the cooperative's capital and the cooperative collectively rented in the individual grazing areas from the families who migrated to live in urban regions, they collectively decided to remove all the wire fences that demarcated individual grazing boundaries and restored the community's collective use of rangelands with seasonal livestock mobility at the community scale. Third, the cooperative consists of four departments, including mechanics for harvesting fodder, a livestock production department, a marketing department, and a tourism department. The cooperative reinforced community management and organizations to regulate their rangeland management systems including prohibiting herders from renting out their rangelands to outsiders.

According to a herder interview (Lai, 2012), this management system generated several key benefits to the local herders. From an ecological aspect, as the cooperative collectively use their rangelands with regulations of no renting of grazing areas to outsiders, the spatial distance of livestock movement has increased, different grazing parcels get a chance to rest and recover, and the overall grazing pressures have been reduced. The remote sensing data from Lai and Li (2012) compared the normalized difference vegetation index (NDVI) values of five paired sites, with each of the pairs including a pasture that has never been leased out (self-use) and its neighboring pasture which used to be self-used (blue area) and then leased out (gray area) and currently under cooperative management (yellow area) pastures. Their study results demonstrate that the level of NDVI in the leased rangeland is lower than when they were self-used, indicating lower vegetation productivity when the rangelands are leased out. When the rangelands are re-aggregated and used collectively under the cooperative management, there are trends of increased NDVI levels. Therefore, differing from the rangeland transfer system that leased out rangelands to different people in many short terms, the rangeland re-aggregation and restoration of seasonal mobility under herder cooperatives help to reduce the overall grazing pressures on individual grazing parcels through the collective use of the rented-in rangelands so that it may be able to prevent and even restore rangeland degradation in the long-term.

Lai's research (2012) demonstrates that the establishment of the herder cooperative helped to improve herder livelihood while protecting their individual benefit and rights. First, based on the number of individual grazing areas or livestock numbers that they have invested in the cooperative, each pastoral household, whether already moved out into urban areas or continuously living in the pastoral regions, is entitled to receiving a share of benefit distribution at the end of the year, based on the cooperative net benefits and income. In addition, the cooperative hired many of the herders who did not have livestock and worked in the urban areas, who decided to come back and work in the cooperative as a long-term employment. Second, the cooperative helped individuals to reduce costs for purchasing fodder and saving livestock production labor under the cooperative management. The average expenditures on fodder purchases accounted for $33-43 \%$ of total livestock production costs in Inner Mongolia after the implementation of the RHCP. The cooperative's members are able to purchase the fodder at a price of 21 yuan/bale in 2011, which is lower than the regular market price of 25-30 yuan/bale. Similarly, the cooperative collectively herd all of the members' sheep. In summer, they hire six shepherds, 
while in winter they only need four. The shepherd's wage is 2,000 yuan/month under the cooperative, and all members only need to support the wage of six shepherds, whereas in the pre-cooperative era, each family may have needed to hire a shepherd. Therefore, each household is only spending $1 / 3$ of the previous costs on shepherd wages.

According to Lai's (2012) interview, some of the herders stated: "After the establishment of the herder cooperative, we do not need to rent out rangelands to others and invested our lands in the cooperative. In this way, we are still earning income from our grazing lands as we did before under the rangeland rental system, but with better care and higher income." As this herder has stated, we believe that this herder cooperative management system demonstrates innovative community-based institutions that stimulate the improvement of livestock production, herder livelihood, and rangeland ecosystem while protecting the individual rights and benefits of herders living in pastoral regions or those who choose to migrate to urban regions.

\section{CASE 2: COMMUNITY-BASED GRAZING QUOTA SYSTEM IN THE TIBETAN PLATEAU}

Our research in the pastoral regions of the Tibetan Plateau discovered that (Gongbuzeren et al., 2016, 2018), while some pastoral communities maintain common community use of rangelands based on their customary institutions, they began to pay attention to the needs of individual households in the rangeland management system (Gongbuzeren et al., 2016). Along with the promotion of the rangeland transfer system that opened up new markets for the rangeland rental system, rangelands are not limited to the resources for livestock production but are used for resources that can be traded for generating income. Following this fundamental change, many herders in the community's collective use of rangelands anticipate a certain level of individualized property rights to protect individual tenure security and benefits. Particularly, those families who do not have livestock and migrated into urban areas strongly demanded clarified property rights so that they can earn income from their individual pastures. However, many of the pastoral communities wanted to maintain collective community use of rangelands to facilitate seasonal livestock mobility at the same time. Given this, recent studies discovered that innovative rangeland management institutions are emerging in the pastoral regions of the Tibetan Plateau, including a group collective use of rangelands (Cao et al., 2013; Gongbuzeren et al., 2020), a community-based grazing quota system (Gongbuzeren et al., 2018), and herder cooperative management (Wang et al., 2016). The community-based grazing quota system is a commonly applied innovative institutions to manage rangeland resources.

In the case of the community-based grazing quota system, C Village, from the pastoral regions of the Tibetan Plateau is located in Guinan County of Qinghai Province. The village has a total of 431 households, with a population of 2,000 Tibetan pastoralists (Gongbuzeren et al., 2016). Livestock production is the main source of household income. Historically, common property rights for range management supported the collective use of rangelands, with seasonal mobility of livestock as the main grazing strategy. Similar to other pastoral communities of the Tibetan Plateau, the C Village was under the commune system from the 1950s to the early 1980s. In 1982, the government initiated the Household Production Responsibility System, privatizing livestock to individual households. Rangelands were left to collective use by the village until the early 1990s, when the government began promoting the Rangeland Household Contract Policy, allocating specific land parcels to households. In C Village, each household received a paper contract from the local government showing the area and location of the rangeland where the household had individual user rights, but the villagers divided up only their winter pasture and continued community collective use of their spring/fall and summer pastures. In 2009, C Village collectively decided to develop a grazing quota system that allowed them to continue the common use of summer and spring/fall pastures and maintain four seasonal livestock migrations each year, while it clarified the individual grazing quota system.

The community-based grazing quota tends to clarify individual grazing quota based on the total livestock numbers that the herders believe their community rangelands can support and sets a quota for livestock numbers for each village member. The individual quota changes every year based on the quality of their grazing area. Quotas can be transferred from one villager to another via a fee system run by the community for those with extra or too few livestock to use their quotas. They charge a fee to households whose livestock numbers exceed their grazing quota and distribute the money as compensation to households using less than the quota so that households without enough livestock still make an income. The community-based grazing quota system clarifies tradeable rights to a share in the grazing quota at the individual household scale so that herding households can maintain mobility, community management practices, and shared labor at the community scale.

According to the studies of Gongbuzeren et al. (2016), this management system generated several benefits for the local herders. First, based on the implementation of the rangeland household contract on paper, the community-based grazing quota system clarified the individual grazing quota that protected individual rights and benefits from rangeland resources. Consequently, many of the poor families who do not have livestock and migrated to urban areas could obtain compensation from rich families who have higher livestock numbers. Second, while the grazing quota system is clarified to an individual household, the community collectively manages and uses rangeland resources for seasonal livestock mobility. This helps the herders control livestock production costs and improve livestock production return. Third, the grazing quota system helps herders control the livestock numbers while not undermining livestock production efficiency so that rangeland degradation is not observed (Gongbuzeren, 2019). 


\section{CONCLUSIONS}

Livelihood transformation under urbanization in the pastoral regions has been a long-term process, where out-migrated herders face many critical livelihood challenges and have to depend on resources from pastoral regions to support their livelihoods, forming complex patterns of linkages between rural and urban regions. In addressing these challenges, we proposed an operational framework in this paper that frames the linkages between herders living in pastoral regions and those living in urban regions within three types of mobilities, including livestock mobility, herder mobility, and resource mobility. However, how these three types of mobilities are maintained becomes a critical challenge for rangeland management institutions, as it requires institutions operating across multiple scales to rebuild cooperation and collective action between the herders living in rural pastoral regions and those living in urban areas. Government policies support the wide implementation of a rangeland transfer system based on further completion of the rangeland household contract policy, though our field research in the pastoral regions of Inner Mongolia and the Tibetan Plateau has discovered that rural communities have developed innovative rangeland management institutions that may provide more effective solutions to maintaining the three types of mobilities to address livelihood challenges in the process of urbanization.

We believe that the discussions of herder livelihood transformation in the process of urbanization and the innovative rangeland institutions in addressing livelihood challenges have some important implications and references to other pastoral regions who face similar challenges, and they require future studies with in-depth scrutiny.

First, this study proposed the assumption that, even though there is an increasing number of studies that have focused on the pull-push factors of herder out-migration and the livelihood challenges that out-migrated herders encounter, very few have focused on how to maintain the linkages between the herders living in rural and urban areas and if such linkages could be key in addressing the livelihood challenges that they face. Livelihood transformation under the urbanization of pastoral regions is a long-term process where herders living in both rural and urban regions need to continually depend on resources from both sides to support their livelihoods. Therefore, we argue that the three types of mobilities discussed in this paper are the key dimensions of rural-urban linkages in the pastoral regions through which herders living in both rural and urban regions can access resources and markets to address their livelihood challenges. This further indicates that discussing social-ecological issues under urbanization in pastoral regions requires a perspective of viewing the herders living in rural pastoral regions and those who live in urban regions as a coupled system, a perspective that has not received adequate attention in the current literature.

Second, we argue that, even though rural-urban linkages are critical, how to maintain them is challenging, especially for rangeland management institutions. In the process of urbanization, many of the out-migrated families demanded clarified property rights to increase their tenure security as well as so that they can rent out their individual grazing parcels to earn income. Therefore, many herders who maintained the collective use of rangelands start to self-organize a more individualized tenure regime. However, contracting rangeland to individuals restricts livestock mobility and the ability to adapt to ecological dynamics for herders living in rural regions. The herders who continue living in the pastoral areas prefer more flexible institutional arrangements that provide access to seasonal grazing. Given this, this paper argues that future studies on rangeland management institutions need to go beyond the traditional debates on whether rangelands should be privatized or managed under common property rights. Some studies already discovered the need for nested property rights and hybrid institutions operating at multiple scales to adapt to changing pastoral social-ecological systems (Gongbuzeren et al., 2018; Qi and Li, 2021), but more studies with empirical fieldwork are needed on rangeland institutional changes and innovations under urbanization.

Third, enabled by the influences of the rapid growth of urbanization and market-based economic development, many of the rural pastoral regions on the Tibetan Plateau are highly integrated with modern marketization. In addition to all the family out-migrations that have mostly occurred under ecological migration and rural education reform policy, there is also much voluntary migration of rural herders, especially young laborers who temporally move to urban areas to seek alternative income sources. Even though many studies focused on the patterns and trends of rural population movements and the pull-push factors behind these movements at provincial and country levels, very few studies have focused on population movements in pastoral regions. Therefore, more empirical and case-based studies are needed to assess the patterns of herder population movements and their impacts on rural pastoral development.

Fourth, urbanization and other rural development policies increased the linkages between rural pastoral regions and the regional or international markets, diversifying the uses and values of rangeland resources. While livestock production is still the main income source of rural herders, they also tend to engage with other rangeland economic activities such as tourism, collection of caterpillar fungus, handicraft sales, and secondary processes of livestock products such as milk liquor or yak milk ice cream. Therefore, both government policies and many research studies raised the importance of building a rural cooperative economy and the re-aggregation of rural resources to improve their abilities to engage with current markets. However, how and at what scale should cooperative economy and collective action be restored, especially after the implementation of the rangeland household contract system, becomes a critical challenge requiring adequate attention from future studies.

\section{DATA AVAILABILITY STATEMENT}

The original contributions presented in the study are included in the article/supplementary material, further inquiries can be directed to the corresponding author/s. 


\section{AUTHOR CONTRIBUTIONS}

G and LW conducted field research in the case village from the Tibetan pastoral regions and drafted the paper, while LY conducted the fieldwork in the case village from Inner Mongolia. All authors contributed to the article and approved the submitted version.

\section{FUNDING}

This paper was supported by the Natural Science Foundation of China (41971256), the Natural Science Foundation of China Youth Project (71703126), the Fundamental Research Funds for the Central Universities

\section{REFERENCES}

Aklilu, Y., and Catley, A. (2010). Mind the Gap: Commercialization, Livelihoods and Wealth Disparity in Pastoralists Areas of Ehiopia. Boston, MA: Tufts University.

Bao, Z. M., and Shi, T. F. (2020). Urbanization and ecological governance in pastoral areas. Soc. Sci. China 3, 146-207. Available online at: https://www.cnki. com.cn/Article/CJFDTotal-ZSHK202003008.htm

Behnke, R. H., Scoones, I., and Kerven, C. (1993). Range Ecology at Disequilibrium: New Models of Natural Variability and Pastoral Adaptation in African Savannas. London: Overseas Development Institute.

Bum, T. (2018). Translating ecological migration policy: a conjunctural analysis of Tibetan pastoralism resettlement in China. Crit. Asian Stud. 50, 518-536. doi: 10.1080/14672715.2018.1515028

Cao, J. J., Yeh, E. T., Holden, N. M., Yang, Y.Y., and Du, G. (2013). The effects of enclosures and land-use contracts on rangeland degradation on the QinghaiTibetan Plateau. Arid. Environ. 97, 3-8. doi: 10.1016/j.jaridenv.2013.05.002

Catley, A., and Aklilu, Y. (2013). "Moving up or Moving out"? Commercialization, growth and destitution in pastoralists areas," in Pastoralism and Development in Africa: Dynamic Change at the Margins, eds A. Cately, J. Lind, and I. Scoones (Abingdon: Routledge).

Catley, A., Lind, J., and Scoones, I. (2013). Pastoralism and Development in Africa: Dynamic Change at the Margins. Abingdon: Routledge.

Chaudhury, A. S., Thornton, T. F., Helfgott, A., Ventresca, M. J., and Sova, C. (2017). Ties that bind: local networks, communities and adaptive capacity in rural Ghana. J. Rural Stud. 53, 214-228. doi: 10.1016/j.jrurstud.2017.05.010

Cleaver, F. (2012). Reinventing institutions: bricolage and the social embeddedness of natural resource management. Eur. J. Dev. Res. 14, 11-30. doi: $10.1080 / 714000425$

Dai, Z., Min, W. Y., and Deng, A. (2009). A case analysis of urban emigrational wishes of herdsmen in Zuo Leaue of Alashan. Soc. Sci. Ningxiang 4, 34-40. Available online at: http://en.cnki.com.cn/Article_en/CJFDTotalLXSK200904007.htm

Du, F. C. (2014). Ecological Resettlement in the Sanjiangyuan of Qinghai. Beijing: China Social Science Press.

Eriksson, C. (2011). What is traditional pastoral farming? The politics of heritage and 'real values' in Swedish summer farms (fäbodbruk). Pastoralism Res. Policy Pract. 1:25. doi: 10.1186/2041-7136-1-25

Fan, M. M., Li, Y. B., and Li, W. J. (2015). Solving one problem by creating a bigger one: the consequences of ecological resettlement for grassland restoration and poverty alleviation in Northwestern China. Land Use Policy 42, 124-130. doi: 10.1016/j.landusepol.2014.07.011

Gongbuzeren (2019). Rangeland Institutional Changes Under Marketization in the Pastoral Regions of the Tibetan Plateau. Chengdu, China: Southwestern University of Finance and Economics Press.

Gongbuzeren, Huntsinger, L., and Li, W. J. (2018). Rebuilding pastoral socialecological resilience on the Qinghai-Tibetan Plateau in response to changes in policy, economics and climate. Ecol. Soc. 23:21. doi: 10.5751/ES-10096-2 30221
(JBK2101035), and the National Research Foundation of Korea Grant (NRF-2017S1A3A2067220).

\section{ACKNOWLEDGMENTS}

We thank all the students in the group for their contributions and discussion during our weekly group meeting, and we want to express our deepest gratitude to the local guide and herders who dedicated time and effort to our fieldwork. We also want to acknowledge that many of the materials and field data in this paper came from the M.A. thesis of LY (2012) and the Ph.D. thesis of G (2016), who were supervised by LW, a co-author of this paper.

Gongbuzeren, Li, Y. B., and Li, W. J. (2015). China's rangeland management policy debates: what have we learned? Rangeland Ecol. Manag. 68, 305-314. doi: 10.1016/j.rama.2015.05.007

Gongbuzeren, Zhang, Z. Y., and Wu, J. Q. (2020). How do market-based rangeland institutional reforms affect herders engagement with credit loans within the pastoral regions of the Tibetan Plateau? J. Rural Stud. 73, 1-9.

Gongbuzeren, Zhuang, M., and Li, W. (2016). Market-based grazing land transfers and customary institutions in the management of rangelands: two case studies on the Qinghai- Tibetan Plateau. Land Use Policy 57, 287-295. doi: 10.1016/j.landusepol.2016.05.035

Huntsinger, L., Forero, L. C., and Sulak, A. (2010). Transhumance and pastoralist resilience in the Western United States. Pastoralism Res. Policy Pract. 1, 10-36. Available online at: https://nature.berkeley.edu/huntsingerlab-wp/wp-content/ uploads/2013/08/104-Huntsinger-transhumance.pdf

Jin, Y., and Li, W. J. (2019). Impacts of spontaneous migration and policydriven migration on the livelihood of pasotralis: a case study in Nangqian County, Yushu Tibetan Autonomous Prefecture of Qinghai Province. Acta Sci. Nat. Univ. Pekinensis 55, 1119-1128. doi: 10.13209/j.0479-8023. 2019.114

Jiumaocuo and Wang, S. L. (2016). Assessment of Agro-Pastoralist Livelihood Condition in the Process of Urbanization in Two Provinces of the Tibetan Plateau. Beijing, China: Science Press.

Kamoto, J., Clarkson, G., Dorward, P., and Shepherd, D. (2013). Doing more harm than good? Community based natural resource management and the neglect of local institutions in policy development. Land Use Policy 35, 293-301. doi: 10.1016/j.landusepol.2013.06.002

Kratli, S. (2019). Pastoral Development Orientation Framework: Focus on Ethiopia, Aachen: Bischofliches Hilfswerk MISEREOR e. V.

Lai, Y. P. (2012). Pasture Transfer and Cooperation's Influence on Herders' Ability to Benefit: A Comparative Study of Pasture Integration Methods After the Grassland Contract Policy (MA thesis). Peking University.

Lai, Y. P., and Li, W. J. (2012). Pasture transfer's impact on Rangeland ecosystem and pastoralists' livelihoods in Arid and semi-arid area: a case study in new Barag Right Banner, Hulunbeir. Chin. Res. Sci. 34, 1039-1048. Available online at: http://en.cnki.com.cn/Article_en/CJFDTOTAL-ZRZY201206011.htm

Li, A., Wu, J., Zhang, X., Xue, J., Liu, Z., Han, X., et al. (2018). China's new rural "separating three property rights" land reform results in grassland degradation: evidence from Inner Mongolia. Land Use Policy 71, 170-182. doi: 10.1016/j.landusepol.2017.11.052

Li, W. J., and Huntsinger, L. (2011). China's grassland contract policy and its impacts on herder ability to benefit in Inner Mongolia: tragic feedbacks. Ecol. Soc. 16:1. doi: 10.5751/ES-03969-160201

Li, W. J., and Zhang, Q. (2009). Understanding Rangeland Challenges: Discovery of Rangeland Use and Management Issues at Arid and Semi-Arid Regions. Beijing, China: Economic Science Press.

Li, Y. N. (2012). A new perspective to urbanization in pastoral regions. J. Peking Univ. 49, 5-10. Available online at: https://www.cnki.com.cn/Article/ CJFDTotal-BDZK201201003.htm 
Li, Y. Y. (2013). Urbanization through ecological migration in the pastoral regions of Inner Mongolia. Inner Mongolia Statistics 3, 9-10. Available online at: http:// d.wanfangdata.com.cn/periodical/nmgtj201303003

Liu, X. Q., and Wang, L. Q. (2008). A literature review on ecological migration in China. China Ecol. Econ. 1, 395-399. Available online at: http://en.cnki.com.cn/ Article_en/CJFDTOTAL-STJX200801106.htm

Miehe, G., Miehe, S., Bohner, J, Kaier, K., Hensen, I., Madsen, D., et al. (2009). How old is the human footprint in the world' largest alpine ecosystem? A review of multiproxy records from the Tibetan Plateau from the ecologists' viewpoint. Palaeogeogr. Palaeoclimatol. Palaeoecol. 276, 130-147. doi: $10.1016 /$ j.palaeo.2009.03.005

MOA (Ministry of Agriculture) (2014). China National Grassland Monitoring Report (QuanGuo CaoYuan JianCe BaoGao). Available online at: http://www. grassland.gov.cn/Grassland-new/Category_11/Index.aspx (accessed May 10, 2014).

Nightingale, A. J. (2011). Beyond design principles: Subjectivity, emotion and the irrational commons. Soc. Nat. Resour. 24, 119-132. doi: 10.1080/08941920903278160

Nori, M., and Scoones, I. (2019). Pastoralism, uncertainty and resilience: global lessons from the margin. Pastoralism 9, 1-7. doi: 10.1186/s13570-019-0146-8

Ojia, H. T., Ford, R., Keenan, R. J., Race, D., Vega, D. C., Baral, H., et al. (2016). Delocalizing communities: channing forms of community engagement in natural resources governance. World Dev. 87, 271-290. doi: 10.1016/j.worlddev.2016.06.017

Ptackova, J. (2011). Sedentarisation of Tibetan nomads in China: implementation of the Nomadic settlement project in the Tibetan Amdo area; Qinghai and Sichuan Provinces. Pastoralism Res. Policy Pract. 1:4. doi: 10.1186/2041-7136-1-4

Qi, Y. G., and Li, W. J. (2021). A nested property right system of the commons: perspective of resource system units. Environ. Sci. Policy 115, 1-7. doi: 10.1016/j.envsci.2020.10.009

Scoones, I., Lin, J., Maru, N., Nori, M, Pappagallo, L., Shariff, T., et al. (2020). Pastoralism and development: fifty years of dynamic change. IDS Bull. 51:1. doi: 10.19088/1968-2020.111

Sheehy, D. P., Miller, D., and Johnson, D. A. (2006). Transformation of traditional pastoral livestock systems on the Tibetan steppe. Secheresse. 17, 142-151.

State Council (2016). Perspectives on further completion of land contract and management rights in agricultural regions of China. [Translated from the Chinese.] Beijing, China: State Council. Available online at: http://www.gov.cn/ xinwen/2016-10/30/content_5126200.htm (accessed September 12, 2019).
Thornton, T. F., and Manasfi, N. (2010). Adaptation-genuine and spurious: demystifying adaptation processes in relation to climate change. Environ. Soc. 1, 132-155. doi: 10.3167/ares.2010. 010107

Wang, J., Wang, Y., Li, S. C., and Qin, D. H. (2016). Climate adaptation, institutional change, and sustainable livelihoods of herder communities in northern Tibet. Ecol. Soc. 21:5. doi: 10.5751/ES-08170210105

Wang, L. J., and Xiu, C. B. (2014). A micro-level analysis of the urbanization of emigrants from Inner Mongolia pastoral areas. China Soft Sci. 3, 76-87. Available online at: http://www.en.cnki.com.cn/Article_en/CJFDTOTALZGRK201403008.htm

Washul, E. (2018). Tibetan translocalities: navigating urban opportunities and new ways of belonging in Tibetan pastoral communities in China. Crit. Asian Stud. 50, 493-517. doi: 10.1080/14672715.2018.15 20606

Yeh, E. T., and Makely, C. (2019). Urbanization, education, and the politics of space on the Tibetan Plateau. Crit. Asian Stud. 51, 1-11 doi: 10.1080/14672715.2018.1555484

Zhang, Z. Y. (2020). Research on the Role of Community Cooperation Institution in the Livelihood Transformation of Herdsmen Families Under the Background of Urbanization (Thesis). Southwestern University of Finance and Economics.

Zhu, J. M. (2018). Transition of villages during urbanization as collective communities: a case study Kunshan, China. Cities 71, 320-328. doi: 10.1016/j.cities.2017.09.009

Conflict of Interest: LY was employed by the company Shenzhen Institute of Building Research, Co., Ltd.

The remaining authors declare that the research was conducted in the absence of any commercial or financial relationships that could be construed as a potential conflict of interest.

Copyright (c) 2021 Gongbuzeren, Wenjun and Yupei. This is an open-access article distributed under the terms of the Creative Commons Attribution License (CC BY). The use, distribution or reproduction in other forums is permitted, provided the original author(s) and the copyright owner(s) are credited and that the original publication in this journal is cited, in accordance with accepted academic practice. No use, distribution or reproduction is permitted which does not comply with these terms. 